\title{
Health Related Quality of Life for Patients with Liver Transplantation
}

\author{
Zeinab Gamal, D.N.Sc; Bahia Galal, D.N.Sc;, Mohamed Ali, M.D. and Magda \\ Mohamed D.N.Sc. \\ The Department of Medical-Surgical Nursing, Faculty of Nursing, Mansoura University, \\ Medical-Surgical Nursing, Faculty of Nursing, Port Said University, Gastrointestinal \\ Surgery, Faculty of Medicine, Mansoura University \& Medical-Surgical Nursing, Faculty of \\ Nursing, Ain Shams University.
}

\begin{abstract}
Background: Liver transplantation has become the best treatment option for cirrhosis, acute liver failure and some tumors. This procedure has become routine with an excellent outcome in terms of both quality and length of survival.
\end{abstract}

Aim: The aim of the current study was to assess health related quality of life for patients with liver transplantation.

Materials and Methods: A descriptive exploratory design was used in this study. A convenience sample consisted of all available patients with liver transplantation at follow-up stage within 6 months at outpatients' of Gastroenterology Center at Mansoura University. Three tools were used for data collection.

Results: The present study concluded that liver transplantation surgery had affected Health Related Quality of life (HRQL) of the study subjects, the highest affected dimensions was for Role Limitation Due to Emotional Health and Social Well-Being, while the least affected dimension was for Role Limitation Due to Physical Health. There was no statistical significant relation between patients' socio-demographic characteristics and their HRQL, except residence and monthly income. There was a highly statistically significant relation between total knowledge of the study subject and their Role Limitation Due to Emotional Health dimension, while there were no statistically significant relation between other dimensions of quality of life and total knowledge score.

Recommendation: Continuous educational programs for patient with liver transplantation and their family about healthy life after liver transplantation, methods, complication and side effects of drugs and signs \& symptoms of infection or rejection.

Keywords: Liver transplantation, Health Related Quality of Life 


\section{Introduction}

LIVER transplantation (LT) is one of the greatest advances of the past 3 decades for the care of patients with hepatic failure and a well-accepted treatment method for end-stage liver disease. It is also one of the most expensive treatments (Vilmanis et al., 2013 \& Singh et al., 2011).

Liver transplantation is the replacement of the native, diseased, liver by a normal organ has matured from an experimental procedure reserved for desperately ill patients to an accepted, lifesaving operation applied much earlier in the natural history of end-stage liver disease. The preferred and technically most advanced approach is orthotropic transplantation, in which the native organ is removed and the donor organ is inserted in the same anatomic location (Kasber et al., 2005).

Transplant medicine is a complex multi-faceted area, requiring the involvement of many specialist teams. The ultimate goal is to improve the length and quality of life in a patient with an irreversible terminal disease (Hogan et al, 2012). The World Health Organization defines Health Related Quality of Life (HRQOL) as a state of wellbeing rather than merely the absence of disease. This definition invites a multi-dimensional approach that encompasses physical improvement as well as life quality and perceived well-being (Wang et al., 2012). HRQOL research presents a challenging goal for clinicians, as it is necessary to convert information based on patient self-assessment and subjective reports into a quantitative measurement that can be standardized and applied to large patient populations. In addition, its interventions and outcomes are based on patient-driven objectives, priorities, interpretations, and satisfaction rather than solely physician-based medical objectives and goals such as mortality, morbidity, length of life, and survival rates (Strauss \& Teixeira, 2006).

From the liver recipients' point of view, pleasant quality of life in the long run is the main goal of transplantation; However post transplant adverse effects influence physical and psychological status of them. The main goal of all health care professionals in liver transplant teams is to help patients move from dependency phase toward independency phase and gain maximum quality of life. Workman implies that caring for liver transplant patients require approach (Tayebi \& Abedi, 2008). 


\section{Significance of the study:}

In Egypt, as a result of the systemic application of living donor liver transplantation (LDLT), the number of adult LDLT performed annually has increased rapidly in the past few years. In January 2010, the number of living donor liver transplants performed topped out to more than one thousand procedures done in 11 canters (Abd-Eldayem, 2010). According to (Marwan et al, 2012 and Abd - Elwahab et al, 2012), the total number of living donor liver transplantation reaching 1600 cases done in about eleven centers across the country. Statistical reports in Gastroenterology Center at Mansoura University reported that, the number of LDLT cases is increasing and reached to 270 cases from the period of 2004 to December 2013.

Over the past decade, as outcome following liver transplantation in terms of patient and graft survival has steadily improved, attention has focused increasingly on the importance of restoring quality of life (QOL) in transplant recipients (Desai et al, 2008).

\section{Aim of study:}

This study aims to assess health related quality of life for patients with liver transplantation.

\section{Research questions:}

To achieve the aim of this study، the following research questions were formulated:

- Does liver transplantation affect the patient's health related quality of life?

- Is there a relation between Socio-demographic characteristics of patients with liver transplantation and their health related QOL?

- Does patients' knowledge regarding liver transplantation affect their health related Q 


\section{Materials and Methods}

Study Design: A descriptive exploratory design was used to conduct this study.

Setting: This study was conducted at outpatients' of Gastroenterology Center in Mansoura University.

Sample: A convenience sample consisted of patients with liver transplantation at follow-up stage within 6 months was recruited in the study (their number was 80 patients) According to these criteria: All adult patients with liver transplantation from both sexes during the first three years after transplantation.

Tools of data collection: Three tools were used for data collection:

Tool I: A structured patients interviewing questionnaire (Appendix I) was developed by the researcher and consisted of two parts. Part (1): Socio-demographic characteristics of the study subjects, which were composed of 10 closed ended questions including age, gender, marital status, level of education, occupation, the nature of work, sources of drinking water, condition of home, residence and monthly income.

Part (2): This part included questions to assess patient's medical history:

a) Past history of the study subjects, which were composed of 6 closed ended questions including duration of liver transplantation, causes of developing hepatic failure, drugs used before transplantation, duration of therapy before transplantation, rejection after transplantation and relative degree of the donors.

b) Present history of the study subjects, which were composed of 9 closed ended questions including associated chronic diseases, GIT problems, urinary problems, skin problems, used medications, regularities of taking medications, Finding of laboratory tests, follow-up program and body mass index.

To calculate the body mass index of the studied sample: Body Mass Index (BMI) refers to the measure expressing the relationship (or ratio) of weight-to-height. BMI is calculated by body weight in kilograms divided by the square of height in meters $\mathrm{Wt} /(\mathrm{Ht})^{2}$ (Mackay, 2010).

$\begin{array}{lll}\text { - } & \text { Under weight: } & <18 \\ \text { - } & \text { Normal body weight: } & 18-<24.9 \\ \text { - } & \text { Overweight: } & 25.0-29.9\end{array}$


- $\quad$ Moderate obesity: $\quad 30.0-39.9$

- $\quad$ Morbid obesity: $\quad \geq 40$

c) Family history of the study subjects, which were composed of 3 closed ended questions including family history of liver diseases, the degree of relativity and family history of liver transplantation.

Tool II: Patient's knowledge questionnaire (appendix II): It was developed by the researcher to assess patient's knowledge about liver transplantation. It consisted of 17 multiple-choice questions, which was divided into five parts:

Part (1): General knowledge about liver transplantation. It was consisted of two closed ended questions, which included definition and causes of liver transplantation.

Part( 2): Questions about complications of transplantation: It was consisted of six closed ended questions, which included complications after transplantation, knowledge of infection hazards, sources of infection, symptoms of infection or rejection, side effects of immunosuppressant drugs and pregnancy after transplantation.

Part (3): Questions about nutrition: It was consisted of two closed ended questions, which included ideal nutritional systems and foods which should avoided after liver transplantation.

Part(4): Questions about physical exercise: It was consisted of three closed ended questions, which included exercise could be practiced by patients, counseling before sports practice and precautions before exercise practice.

Part (5): Questions about personal care: It was consisted of four closed ended questions, which included importance of personal care, methods of personal care, problems that occur after prolonged exposure for sunrays and precautions during exposure of sunrays.

\section{Scoring system of Knowledge questionnaire sheet:}

Knowledge questionnaire sheet consisted of 17 multiple choice questions, each point is scored 0 for incorrect answer and 1 for correct answer and the total knowledge score is 82 . Total patients' knowledge score was classified into two groups: satisfied knowledge if score $\geq 70 \%$ from the total score and unsatisfied knowledge if the score is $<70 \%$.

Tool III: Health Related Quality of Life Scale (SF-36) is defies the Rand 36-item health survey, version1 (appendix III): 
Hays, Shapiro, Stewart, and Sherbourne (1992), adopted this tool. It consisted of 36 items that assess eight health concepts: physical functioning questions: (3-12); role limitations due to physical health problems questions:( 13-16); role limitations due to emotional problems questions:(17-19); energy/fatigue questions:(23-27-29-31); emotional well-being questions:(24-25-26-28-30); bodily pain questions: (21 and 22); social functioning questions: (20 and 32) and general health perceptions questions: (1,2,33-36).

Scoring system of Rand 36-items questionnaire:

All questions were scored on a scale from 0 to 100, with 100 representing the highest level of functioning possible. The scores of the items were summed up and the total divided by the number of the items, giving a mean score. These scores were expressed in means and standard deviations.

Operational Design: The Operational design included preparatory phase, content validity, pilot study and fieldwork. Preparatory phase: It included reviewing of related literature and theoretical knowledge of various aspects of the study using books, articles, internet periodicals and magazines to develop the tool for data collection.

Content validity: It was ascertained by a jury of seven expertises from medical and nursing staff. Three of them from Port Said University (They were two assistants professors and one lecture of nursing) and four from Mansoura University (They were two professors and one assistant professor of nursing and one lecture of medicine) to review the tools for clarity, relevance and comprehensiveness.

Testing reliability: It was done through Cronbach Alpha Reliability Test that measure the degree of reliability for the entire form. Both technique showed high reliability for the final version of the tool (Alpha $=.983)$.

Pilot study: A pilot study was applied on a group of 8 patients for testing clarity, arrangement and time consuming to fill in the tools, the modification was done for the used tools then the final form was developed. Patients includes in the pilot study are excluded from the study group.

Fieldwork: The actual fieldwork started from beginning of January 2013 to the end of June 2013 (Within 6 months).

After the researcher explained the aim of the study to patients, the interview process was started by filling in the interview questionnaire, knowledge questionnaire then quality of life questionnaire. The researcher reviewed each point in front of patients to be sure that no points 
were missed.

The researcher visited the outpatients' clinic from 9:00a.m to 2:00p.m.two days weakly. The time needed for completing the questionnaire was about 30-45 minutes.

Statistical analysis:

All data coded, entered and analyzed by using SPSS, (Statistical Package for Social Sciences), soft-ware program version 16. Data were presented in tables, figures and diagram. Statically significant associations were assessed using percentage (\%), mean, standard deviation, f-test, $\mathrm{p}$ value and coefficient relations. Statistical significance was considered at $\mathrm{p}$ value $<0.05$.

\section{Results}

Fig. 1 shows that means of health related quality of life dimensions among patients of the study subjects. The highest affected dimension was for Role Limitation Due to Emotional Health with mean of $81.67 \pm 31.78$, while the least affected dimension was Role Limitation Due to Physical Health with mean of $24.37 \pm 6.37$.

Table 1 shows that, there was no statistically significant relation between dimensions of quality of life and residence except General Health dimension of health related quality of life $(\mathrm{P}=.038 *)$.

Table 2 shows that, there was statistically significant relation between General Health and Total HRQL dimensions of health related quality of life and monthly income $\left(\mathrm{P}=.008^{*} \&\right.$ $\left..03^{*}\right)$ respectively, but there was no statistically significant relation between the others dimensions of health related quality of life and monthly income. Table 3 shows that, there was a highly statistically significant relation between total knowledge scores of the study subject and their role limitation due to emotional health dimension $(\mathrm{P}=0.003 * *)$, while there was no statistically significant relation between other dimensions of health related quality of life and total knowledge score. There was negative relation between Role Limitation Due to Emotional Health dimension and total knowledge scores.

\section{Discussion}

The results of the current study showed that less than half of the study subjects were in age group of more than or equal fifty years old, more than two thirds of them had high educational levels, and most of the them were working and living in urban areas.

Concerning the highest affected dimension of quality of life, the current study showed that, it was for role limitation due to emotional well being. This result is in accordance with (Saab et al., 2011), who reported the same result, While this result is disagreement with (Volk \& 
Hagan, 2011and Berg-Emons et al., 2006), who mentioned that the highest affected dimensions of quality of life were social functioning, and physical functioning respectively. Regarding the least affected dimension of health related quality of life, the current study revealed that, it was for role limitation due to physical functioning which goes in the same line with (Saab et al., 2011 ; Berg-Emons et al., 2006), who found the same results. But this finding is disagreement with (Volk \& Hagan, 2011), who mentioned that the least affected dimension of quality of life was energy/ fatigue.

There was no statistically significant relation between dimensions of HRQOL and residence except at general health dimension. This result is consistent with (Mendes et al, 2013), showed that there was no statistically significant relations between all dimensions of quality of life and residence

Considering the relation between HRQOL dimensions and monthly income, there was statistically significant relations between General Health dimension and total score of health related quality of life dimensions and monthly income, but there was no statistically significant relation between others HRQOL dimensions and patients' monthly income. These findings are in contrast with (Nagah, 2012) who revealed that there was statistically significant relation between physical functioning and social well-being dimensions of quality of life and monthly income three months post liver transplantation. These differences may be related to different duration of liver transplantation.

Concerning to the relation between HRQOL dimensions and total knowledge scores of the study subjects, there was a highly statistically significant relation between total knowledge score of the study subject and their role limitation due to emotional health dimension, while there was no statistically significant relation between other dimensions of quality of life and total knowledge. This result reveals that, patients' knowledge didn't affect their HRQOL except at their role limitation due to emotional health dimension.

\section{Conclusion}

Based on the results of the present study, the following could be concluded that liver transplantation surgery affects on Health Related Quality of life of the study subjects, in which the highest affected dimensions were for Role Limitation Due to Emotional Health, Social Well-Being and Emotional Well-Being, while the least affected dimension was for Role Limitation Due to Physical Health.

There was no statistical significant relation between patients' Socio-demographic 
characteristics and their Health Related Quality of life, except residence of patients \{ which there was statistical significant relation between residence and General Health dimension of health related quality of life $(\mathrm{P}=.038)\}$ and monthly income of patients $\{$ which there was statistical significant relation between General Health and Total HRQL score and monthly income $(\mathrm{P}=.008 \& .03)$ respectively $\}$.

There was a highly statistically significant relation between total knowledge score of the study subjects and their Role Limitation Due to Emotional Health dimension, while there was no statistically significant relation between other dimensions of health related quality of life and total knowledge score of the study subjects.

On the light of the results of the current study, the following recommendations are suggested:

- Continuous educational programs for patient with liver transplantation and their family about healthy life after liver transplantation, methods, complication and side effects of drugs and signs and symptoms of infection or rejection.

- A brief quality of life questionnaire as SF- 36 should be applied as a routine work in the out patients liver transplantation surgery clinic in order to detect early evolving problems affecting the quality of life for patients with liver transplantation surgeries.

- Developing further research about the factors that affect quality of life for patients after liver transplantation surgery

on large probability sample in various settings in order to generalize the results.

\section{References}

Abd-Eldayem, H. (2010). Transparency and Living Donor Liver Transplantation in Egypt, Nile Liver Journal; vol 1 (1): 7-13.

Abd-Elwahab, M., Gad El hak, A., El shobary, M., et al. (2012). Living Donor Liver Transplantation: Retrospective and Prospective study, un published thesis, Doctoral degree, GIT, Mansoura university, Egypt.

Desai, R., Jamieson, N. and Alexander, E. (2008). Quality of Life up to 30 years Following Liver Transplantation. Liver transplantation; vol (14), 1473-9.

Hogan, B., Rahman, S., O’Beirne, J., et al. (2012). Liver and Pancreatic Transplantation. Transplantation; vol 13(6): 292-7.

Kasber, D., Anthony, S., Longo, F., et al. (2005). Harrison's Principles of Internal Medicine. $\left(16^{\text {th }}\right)$ edition, McGraw-Hill medical publishing division, U.S.A., P. 1873. 
Mackay, (2010). Scaling of Human Body Mass with Height: The body Mass Index Revisited. Journal of Biomechanics; vol 43 (4). 764-6.

Marwan, I., Ibrahim, T. and Tanaka, K. (2012). Ten Years of LDLT: Outcome Data from the Egyptian Liver Transplantation Registry. (Quoted) from a presentation by prof. Ibrahim Marwan at Egyptian Society of surgeon's conference, Port Said, Egypt, April 2012.

Mendes, K., Castro e Silva, O., Ziviani, L., C., et al. (2013). Educational Intervention for Liver Transplantation Candidates. Rev. Latino-Am. Enfermagem; vol 21(1): 419-25.

Nagah, S. (2012). Health-Related Quality of Life pre and post liver transplantation. Unpublished Master's Thesis, In Nursing Science. Faculty of Ng, Ain Shames University, Egypt.

Saab, S., Bownik, H., Ayoub, N., et al. (2011). Differences in Health-Related Quality of Life Scores after Orthotopic Liver Transplantation with Respect to Selected Socioeconomic Factors. Liver transplantation journal; vol 17(5): 580-90.

Singh, A., Cronin, C., Verma, H., et al. (2011). Imaging of Preoperative Liver Transplantation in Adults: What Radiologists Should Know. Radio Graphics journal; vol (31): 1017-30.

Strauss, E. and Teixeira, M. (2006). Quality of Life in Hepatitis C. Liver Int; vol (26): 755-65.

Tayebi, Z. and Abedi, H.,(2008). The lived Experiences of Liver Transplant Patients. IJNMR; vol 13(2): 73-80.

Vilmanis, J., Ozolins, A. and Gardovskis, J. (2013). Liver Transplantation: Surgical Aspects. Proc. Latvian Acad. Sci., Section B, vol 67(1): 9-13.

Volk, M. and Hagan, M. (2011). Organ Quality and Quality of Life after Liver Transplantation. Liver transplantation journal; vol (17): 1443-7.

Van den Berg-Emons, R., Kazemier, G., van Ginneken, B., et al. (2006). Fatigue, Level of Every day Physical Activity and Quality of Life after Liver Transplantation. J Rehabil Med; vol (38): 124-9.

Wang, G., Yang, Y., Li, H., et al. (2012). Health-Related Quality of Life after Liver Transplantation: The Experience from a Single Chinese Center. Hepatobiliary Pancreat Dis Int; vol 11(3): 262-6. 


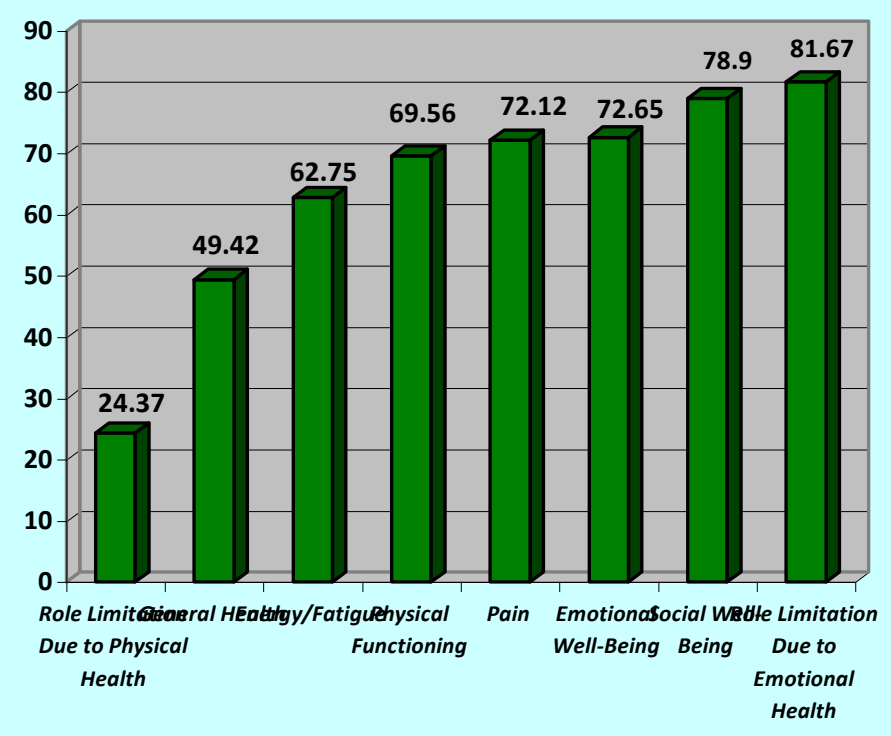

$\square$ Sf 36

Fig. (1): Percentages Distribution of Patients with Liver Transplantation According to the SF 36 Domains. $(\mathrm{n}=80)$.

Table (1): Relation between HRQOL of the Study Subject and their Residence

\begin{tabular}{|c|c|c|c|c|c|c|}
\hline \multirow{3}{*}{ SF Domains } & \multicolumn{4}{|c|}{ Residence } & \multirow{3}{*}{$\mathbf{f}$} & \multirow{3}{*}{ Sig. } \\
\hline & \multicolumn{2}{|c|}{ Rural } & \multicolumn{2}{|c|}{ Urban } & & \\
\hline & mean & \pm SD & mean & \pm SD & & \\
\hline Physical Functioning & 71.101 & 14.85 & 65.238 & 11.987 & 2.649 & .108 \\
\hline $\begin{array}{l}\text { Role Limitation Due to } \\
\text { Physical Health }\end{array}$ & 26.949 & 29.066 & 19.047 & 20.773 & 1.309 & .256 \\
\hline $\begin{array}{l}\text { Role Limitation Due to } \\
\text { Emotional Health }\end{array}$ & 85.310 & 29.859 & 71.428 & 35.411 & 3.032 & .086 \\
\hline Energy/Fatigue & 62.881 & 10.796 & 62.381 & 8.605 & .037 & .849 \\
\hline Emotional Well-Being & 73.152 & 9.883 & 71.238 & 7.224 & .660 & .419 \\
\hline Social Well-Being & 80.296 & 15.257 & 75.000 & 13.110 & 2.001 & .161 \\
\hline Pain & 73.686 & 17.813 & 67.738 & 14.660 & 1.883 & .174 \\
\hline General Health & 50.847 & 10.229 & 45.436 & 9.673 & 4.454 & $.038^{*}$ \\
\hline Total & 63.954 & 11.604 & 58.518 & 8.737 & 3.824 & .054 \\
\hline
\end{tabular}


Table (2): Relation between HRQOL Dimensions of Study Subjects and their Monthly Income

\begin{tabular}{|c|c|c|c|c|c|c|}
\hline \multirow{3}{*}{ SF Domains } & \multicolumn{4}{|c|}{ Monthly Income } & \multirow[b]{3}{*}{ f } & \multirow[b]{3}{*}{ Sig. } \\
\hline & \multicolumn{2}{|c|}{ Enough } & \multicolumn{2}{|c|}{ Not enough } & & \\
\hline & mean & \pm SD & mean & \pm SD & & \\
\hline Physical Functioning & 72.857 & 15.496 & 67.00 & 12.942 & 3.391 & .069 \\
\hline $\begin{array}{l}\text { Role Limitation Due to } \\
\text { Physical Health }\end{array}$ & 25.714 & 27.443 & 24.222 & 27.364 & .058 & .810 \\
\hline $\begin{array}{l}\text { Role Limitation Due to } \\
\text { Emotional Health }\end{array}$ & 89.523 & 26.533 & 75.556 & 34.377 & 3.946 & .051 \\
\hline Energy/Fatigue & 64.857 & 10.536 & 61.111 & 9.763 & 2.704 & .104 \\
\hline Emotional Well-Being & 74.400 & 10.091 & 71.288 & 8.411 & 2.260 & .137 \\
\hline Social Well-Being & 80.714 & 15.560 & 77.500 & 14.252 & .924 & .339 \\
\hline Pain & 75.285 & 18.005 & 69.667 & 16.242 & 2.143 & .147 \\
\hline General Health & 52.857 & 9.733 & 46.759 & 10.046 & 7.453 & $.008^{*}$ \\
\hline Total & 65.571 & 11.001 & 60.160 & 10.768 & 4.878 & $.03 *$ \\
\hline
\end{tabular}

Table (3): Relations between Total Knowledge Score of Patients Study and their HRQOL Dimensions

\begin{tabular}{||l|c|c||}
\hline \multirow{2}{*}{\multicolumn{1}{c|}{ QOL Dimensions }} & \multicolumn{2}{c|}{ Total knowledge } \\
\cline { 2 - 3 } & Pearson Correlation & Sig. \\
\hline \hline Physical Functioning & .060 & 0.584 \\
\hline Role Limitation Due to Physical Health & -.064 & 0.572 \\
\hline Role Limitation Due to Emotional Health & 0.325 & $0.003^{* *}$ \\
\hline Energy/Fatigue & 0.163 & 0.149 \\
\hline Emotional Well-Being & 0.179 & 0.112 \\
\hline Social Well-Being & 0.087 & 0.444 \\
\hline Pain & 0.04 & 0.723 \\
\hline General Health & 0.181 & 0.109 \\
\hline \multicolumn{1}{|c|}{ Total } & 0.113 & 0.318 \\
\hline
\end{tabular}




\section{جودة الحياة الصحية لمرضى زارعة الكبا}

زينب جمال ححمد اللطيف، بهية جلال عبد الرازق، ماجدة عبد العزيز ححم، ححمد عبد الوهاب علي

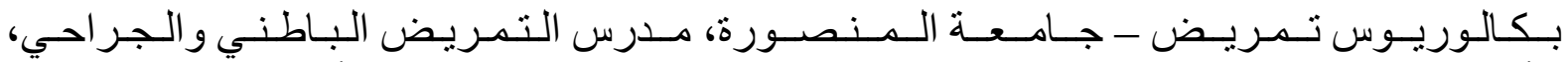

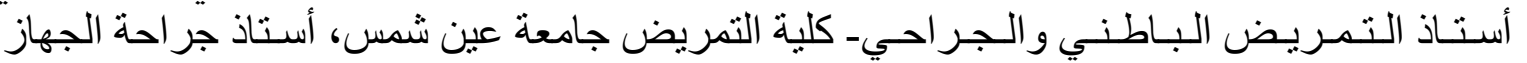

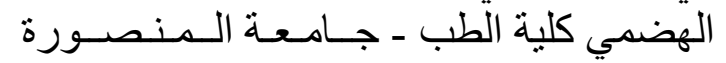

\section{الخلاصة}

عملية زر اعـة الكبد هو الخيـار العلاجي الوحيد المقبول هذة الأيـام بالنسبة لمرضـي الكبد في مر احله النهائية. على مدى السنو ات القليلة الماضية، أصبح تقييم جودة الحياة الصحية للمرضى الخاضعين لعمليات زر اعة الكبد منز ايد الأهمية وقد أثثتت الدر اسات أن جوده الحياة قد تحسنت بشكل كبير بعد الزرع. تهدف

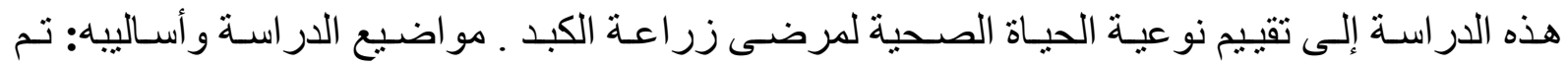
استخدام التصميم الوصفي الاستكشافي لإجر اء هذه الدراسة. أُجربت هذه الدر اسـة فى العيادات الخارجيـة بمركز الجهاز الهضمي بجامعة المنصورة. تم التعامل مع كل مرضي زر اعة الكبد الموجودين بالعيادات الخارجية بمركز الجهاز الهضمي بجامعة المنصورة خلال ثناث سنوات من الزرع حيث تمث الدر اسـة

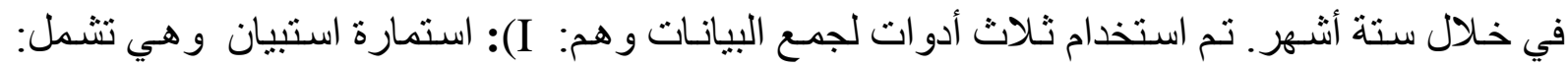
بيانات المريض الاجتماعية والديمو غر افية والتاريخ الطبي للمرضي. Y): استمارة استبيان لتقييم معلومات المرضى تجاه عملية زر اعة الكبد. ب): جودة الحياة الصحية ( SF 36 ، version1). خُلُصت نتائج هذه الدر اسة أن جر احة زر اعة الكبد قد أثنرت علي الجودة الصحية للمرضي الخاضـعين للار اسة ،حيث كانت أكثر أبعاد جودة الحياة تأثر ا هي بُعد القيود بسبب الحالة النفسية، بينمـا الأقل تأثراً كـان بُعد القيود بسبب الحالـة الصـحية الجسـمانية .لا نوجد علاقـة ذات دلالـة إحصـائية بين خصـائص البيانات الشخصية ومقياس جودة الحياة ماعدا مكان الاقامة للعينة، و أيضاً الدخل الثـهري للمرضـي. كمـا أوضـحت الدر اسـة أن هنـالك علاقة بين معلومـات المرضـي عن زر اعـة الكبد وبُعد القيود بسبب الحالـة النفسية. كانت من توصيات البحث تقديم بر امج تعليميـة مستمرة لمرضـي زر اعـة الكبد و عائلاتهم حول طرق الحيـاة الصـحية الصـحيحة، والمضـاعفات، و الأعر اض الجانبيـة للأدويـة التي يتناولهـا، وأعر اض و علامات ألعدوي. الكلمات الدالةة : عملية زراعة الكبد ، جودة الحياة الصحية 